\title{
KARAKTERISTIK DAN PENGOBATAN PASIEN DIABETES MELLITUS DI RUMAH SAKIT PANGLIMA SEBAYA PASER
}

\author{
Ade Purnama Septiani, Rolan Rusli, Laode Rijai \\ Laboratorium Penelitian dan Pengembangan FARMAKA TROPIS Fakultas Farmasi \\ Universitas Mulawarman, Samarinda, Kalimantan Timur \\ email: adepurnamaseptiani2@gmail.com
}

\begin{abstract}
Diabetes mellitus (DM) is one of the major health problems, every year the number of patients keep increase. DM can cause chronic complications, will degrade the quality of human resources. Drug interactions occur when the effect of a medication change because other drugs, food, or beverages. The best therapeutic treatment concerning the selection and administration of drugs is very beneficial for the patient. This study aims to determine the type and prevalence of DM, characteristics, and use of medications, and potential drug interactions in the treatment of Diabetes Mellitus. Observational study was conducted using retrospective data DM medical records of all patients in Panglima sebaya Paser's hospital. Then the data are taken randomly 30 patients for further analysis. The Most type of Diabetes Mellitus is NIDDM ( Non Insulin Dependent Diabetes Melitus) as much 1.148 patients, the most characteristic is patients aged $45-59$ years (76.66\%), female $(66.64 \%)$, primary school education (34.6\%), and not work (86.9\%), and has a family history of diabetes (55.6\%). The most used drug in the treatment of diabetes is metformin (32.5\%) of the biguanide class. Drug interactions are the most common is Insulin with captopril $(46 \%)$.
\end{abstract}

Keywords: Diabetes mellitus, patient characteristics, drug use, drug interactions

\begin{abstract}
ABSTRAK
Diabetes mellitus (DM) merupakan salah satu masalah kesehatan yang besar, setiap tahunnya jumlah pasiennya terus meningkat. DM dapat menyebabkan komplikasi kronik, akan menurunkan kualitas sumber daya manusia. Interaksi obat terjadi jika efek suatu obat berubah akibat adanya obat lain, makanan, atau minuman. Terapi pengobatan yang baik dan benar terkait pemilihan dan pemberian obat sangat menguntungkan bagi pasien. Penelitian ini bertujuan untuk mengetahui tipe dan prevalensi penyakit DM, karakteristik, dan penggunaan obat, serta potensi interaksi obat pada terapi penyakit DM. Penelitian dilakukan secara observasional menggunakan data retrospektif rekam medik seluruh pasien DM di Rumah Sakit Panglima Sebaya Paser tahun 2013. Kemudian diambil secara acak data 30 pasien untuk dianalisis lebih lanjut. Tipe DM yang terbanyak adalah DM tipe 2 sebanyak 1.148 pasien, dengan karakteristik terbanyak adalah pasien berusia $\geq 45$ tahun (76,66\%), berjenis kelamin wanita $(66,64 \%)$, berpendidikan Sekolah Dasar $(34,6 \%)$, dan tidak bekerja $(86,9 \%)$, serta memiliki sejarah keluarga pengidap DM $(55,6 \%)$. Obat yang paling banyak digunakan pada terapi DM adalah Metformin (32,5\%) dari golongan biguanid. Interaksi obat yang paling banyak terjadi yaitu Insulin dengan captopril (46\%).
\end{abstract}

Kata kunci: Diabetes mellitus, karakteristik pasien, penggunaan obat, interaksi obat 


\section{PENDAHULUAN}

Diabetes mellitus (DM) merupakan salah satu masalah kesehatan yang besar. Data dari studi global menunjukkan bahwa jumlah penderita DM pada tahun 2011 telah mencapai 366 juta orang. Jika tidak ada tindakan yang dilakukan, jumlah ini diperkirakan akan meningkat menjadi 552 juta pada tahun 2030 (IDF, 2011). DM merupakan penyakit metabolik yang ditandai dengan hiperglikemia disebabkan karena abnormalitas metabolisme karbohidrat, lemak, dan protein yang dapat mengakibatkan komplikasi kronik seperti mikrovaskuler, makrovaskuler, dan neuropatik (Triplitt, dkk., 2005).

Melihat bahwa DM akan memberikan dampak terhadap kualitas sumber daya manusia dan peningkatan biaya kesehatan yang cukup besar, maka sangat diperlukan program pengendalian. DM bisa dicegah, ditunda kedatangannya, atau dihilangkan dengan mengendalikan faktor resiko (Kemenkes, 2010). Faktor resiko penyakit tidak menular, termasuk DM, dibedakan menjadi dua. Yang pertama adalah faktor resiko yang tidak dapat berubah misalnya jenis kelamin, umur, dan faktor genetik. Yang kedua adalah faktor resiko yang dapat diubah misalnya kebiasaan merokok (Bustan, 2000). Penelitianpenelitian yang telah dilakukan sebelumnya menyatakan bahwa demografi, faktor perilaku dan gaya hidup, serta keadaan klinis atau mental berpengaruh terhadap kejadian DM Tipe 2 (Irawan, 2010).

Interaksi obat terjadi jika efek suatu obat (index drug) berubah akibat adanya obat lain (precipitant drug), makanan, atau minuman. Interaksi obat dapat menghasilkan efek yang memang dikehendaki (Desirable Drug Interaction), atau efek yang tidak dikehendaki (Undesirablel Adverse Drug Interactions $=$ ADIs) yang lazimnya menyebabkan efek samping obat dan/atau toksisitas karena meningkatnya kadar obat di dalam plasma, atau sebaliknya menurunnya kadar obat dalam plasma yang menyebabkan hasil terapi menjadi tidak optimal. Sejumlah besar obat baru yang dilepas di pasaran setiap tahunnya menyebabkan munculnya interaksi baru antar obat akan semakin sering terjadi (Retnowati,2008).

Medication Error merupakan suatu bentuk kesalahan dalam bidang kedokteran dan kefarmasian, yang selama ini selalu luput dari perhatian, cenderung diabaikan, atau bahkan dianggap sebagai kegagalan terapi. Kesalahan peresepan ini dapat memberikan resiko yang berarti bagi pasien. Studi Standar Pelayanan Medik yang telah dilakukan Fakultas Kedokteran Universitas Gajah Mada antara tahun 2001-2003 mengenai Tingkat kesalahan pengobatan atau medication error di Indonesia menunjukkan medication error mencapai $5,07 \%$. Dari jumlah tersebut $0,25 \%$ berakhir fatal hingga kematian. Suatu terapi pengobatan yang baik dan benar terkait pemilihan dan pemberian obat akan sangat menguntungkan bagi pasien, baik dari segi kesehatan atau kesembuhan penyakit yang diderita, biaya yang harus dikeluarkan, potensi interaksi yang mungkin ditimbulkan, dan kepatuhan pasien dalam mengkonsumsi obat tersebut terutama sekali bagi pasien yang harus mengkonsumsi obat dalam waktu yang lama, bahkan seumur hidupnya, seperti penyakit DM. Oleh karena itu efisiensi dan efektivitas penggunaan obat merupakan faktor yang penting diperhatikan (Susilowati,2008).

Mengingat Adverse Drug Reaction (ADR) dan Adverse Drug Interactions (ADIs) yang mungkin ditimbulkan pada penyakit DM merupakan masalah kesehatan masyarakat yang sangat serius terkait penatalaksanaannya dengan terapi obat yang memerlukan jangka waktu lama dan dapat berakibat mempengaruhi kualitas hidup pasien. Jumlah pasien DM di Indonesia semakin lama semakin meningkat maka perlu dilakukan 
penelitian terhadap karakteristik, penggunaan obat, dan potensi interaksi yang mempengaruhi efektivitas terapi untuk mengurangi terjadinya medication error. Penelitian karakteristik, penggunaan obat, dan potensi interaksi DM dilakukan di Rumah Sakit Umum Daerah (RSUD) Panglima Sebaya Paser.

\section{METODE PENELITIAN}

Penelitian Diabetes Mellitus dilakukan secara observasional dari data retrospektif di Rumah Sakit Panglima Sebaya Paser. Dari keseluruhan data rekam medik pasien DM, dipilih secara acak 30 sampel data rekam medik pasien yang akan dianalisis lebih lanjut berupa Kajian penggunaan obat dan interaksi obat pada terapi DM yang dilakukan.

\section{HASIL DAN PEMBAHASAN}

\section{Karakteristik Pasien Diabetes Mellitus}

Karakteristik pasien diabetes mellitus merupakan gambaran dari pasien yang tercatat pada rekam medis yaitu berupa data jenis kelamin, usia, tingkat pendidikan, pekerjaan dan sejarah keluarga (family history), seperti disajikan dalam Tabel 1.

Tabel 1. Karakteristik pasien Diabetes Mellitus di Rumah Sakit Panglima Sebaya Paser Tahun 2013

\begin{tabular}{|c|c|c|}
\hline Karakteristik Pasien DM Berdasarkan & Jumlah & Persen \\
\hline \multicolumn{3}{|l|}{ A. Usia } \\
\hline a. 10-18 tahun & 11 & $0,95 \%$. \\
\hline b. 19-44 tahun & 257 & $22,4 \%$ \\
\hline c. 45-59 tahun & 593 & $51,65 \%$ \\
\hline \multirow[t]{2}{*}{ d. 60-74 tahun } & 287 & $25 \%$ \\
\hline & 1.148 & $100 \%$ \\
\hline \multicolumn{3}{|l|}{ B. Jenis Kelamin } \\
\hline a. Laki-laki & 383 & $33,36 \%$ \\
\hline b. Perempuan & 765 & $66,64 \%$ \\
\hline Total & 1.148 & $100 \%$ \\
\hline \multicolumn{3}{|l|}{ C. Tingkat Pendidikan } \\
\hline a. Tidak sekolah & 184 & $16 \%$ \\
\hline b. Sekolah Dasar & 396 & $34,6 \%$ \\
\hline c. Sekolah Menengah Pertama & 207 & $18 \%$ \\
\hline d. Sekolah Menengah Atas & 118 & $10,3 \%$ \\
\hline e. Diploma / Sarjana & 86 & $7,5 \%$ \\
\hline f. Tidak ada informasi & 157 & $13,6 \%$ \\
\hline Total & 1.148 & $100 \%$ \\
\hline \multicolumn{3}{|l|}{ D. Pekerjaan } \\
\hline a. Bekerja & 998 & $86,9 \%$ \\
\hline b. Tidak Bekerja & 150 & $13,1 \%$ \\
\hline Total & 1.148 & $100 \%$ \\
\hline \multicolumn{3}{|l|}{ E. Sejarah Keluarga } \\
\hline a. Memiliki sejarah keluarga penderita DM & 642 & $55,6 \%$ \\
\hline b. Tidak memiliki sejarah keluarga penderita DM & 506 & $44,4 \%$ \\
\hline Total & 1.148 & $100 \%$ \\
\hline
\end{tabular}


Berdasarkan Tabel 1, menunjukkan bahwa Kelompok umur yang paling banyak menderita diabetes mellitus adalah kelompok umur 45-59 tahun (51,65\%). Pada usia remaja (10-18 tahun) dan usia produktif (19-44 tahun) kebanyakan pasien terserang DM karena faktor keturunan. Umumnya, terjadi akibat kerusakan sel $\beta$ sehingga insulin tidak dapat diproduksi. Pada usia lebih dari 45 tahun kebanyakan pasien terserang DM akibat faktor gaya hidup. Pada usia tersebut mulai terjadi peningkatan intoleransi glukosa. Adanya proses penuaan menyebabkan berkurangnya kemampuan sel $\beta$ pankreas dalam memproduksi insulin diiringi timbulnya dampak gaya hidup di waktu berusia muda (remaja dan produktif), sehingga meningkatkan resiko terserang DM. Gaya hidup yang tidak sehat seperti rokok dan alkohol dan tidak melakukan cek kesehatan rutin, pada saat usia muda membuat pasien mudah terserang diabetes mellitus di usia pertengahan. Pada usia di atas 60 tahun terdapat penurunan aktivitas mitokondria di selsel otot sebesar 35\%. Hal ini berhubungan dengan peningkatan kadar lemak di otot sebesar 30\% dan memicu terjadinya resistensi insulin. Di Indonesia, kebanyakan penderita diabetes disebabkan gaya hidup. Oleh sebab itu, kebanyakan pasien terserang di usia pertengahan (Trisnawati dan Soedijono, 2013).

Berdasarkan Tabel 1, terlihat bahwa Prevalensi kejadian DM pada wanita lebih tinggi daripada laki-laki. Wanita lebih berisiko mengidap diabetes karena secara fisik wanita memiliki peluang peningkatan indeks masa tubuh yang lebih besar. Sindrom siklus bulanan (premenstrual syndrome), pascamenopouse yang membuat distribusi lemak tubuh menjadi mudah terakumulasi akibat proses hormonal tersebut sehingga wanita berisiko menderita diabetes mellitus (Trisnawati dan Soedijono,2013). Wanita memiliki hormon estrogen yang berperan sebagai hormon seks pada wanita. Hormon estrogen dapat membantu metabolisme lemak dan mengatur pola distribusi lemak di bawah kulit sehingga membentuk tubuh wanita. Ketika wanita mengalami menopouse maka terjadi penumpukkan lemak yang beresiko mengalami gangguan toleransi glukosa. Penumpukan lemak akan menyebabkan terganggunya kemampuan insulin untuk mempengaruhi pengambilan glukosa dan metabolismenya pada jaringan yang sensitif terhadap insulin (yang sering disebut resistensi insulin) serta meningkatan sekresi insulin plasma. Pengurangan pengambilan glukosa yang distimulasi insulin pada jaringan perifer dan peningkatan produksi glukosa hepatik akan mengganggu penghambatan pengeluaran glukosa dari hati oleh insulin pada saat puasa. Ketika terjadi penumpukan lemak, pada sel pasien terjadi pengurangan hubungan pengikatan insulin dengan reseptor spesifik, pengurangan aktivitas reseptor insulin tirosin kinase, pengurangan aktivitas transpor glukosa dan pengurangan jumlah dan aktivitas glycogen synthase (Hirsch dan Aronne,1995). Pada lak-laki terdapat hormon androgen yang berperan sebagai hormon sex. Hormon ini juga terdapat pada wanita meskipun dalam jumlah yang sedikit yaitu androstenedione. Androstenedione pada wanita berperan sebagai prohormon dan dikonversi dalam jaringan target menjadi estron dan estradiol. Perempuan dan laki-laki samasama memiliki hormon sex. Tetapi pada wanita hormon sex yang dimiliki lebih banyak. Hormon sex pada laki-laki digunakan untuk membentuk tubuh lakilaki melalui pembentukan jaringan otot yang baik (Wibowo,2005). Jumlah lemak pada laki-laki dewasa rata-rata berkisar antara 15-20\% dari berat badan total, dan pada perempuan sekitar 20-25\%. Jadi peningkatan kadar lipid (lemak darah) pada perempuan lebih tinggi dibandingkan pada laki laki, sehingga 
faktor risiko terjadinya Diabetes Mellitus pada perempuan 3-7 kali lebih tinggi dibandingkan pada laki - laki yaitu 2-3 kali (Jelantik dan Erna, 2014).

Tingkat pendidikan tidak berpengaruh terhadap angka kejadian penyakit Diabetes Melitus. Karena masyarakat yang berpendidikan rendah (Tidak sekolah-SD-SMP), biasanya tinggal di daerah pedesaan atau dusundusun yang jauh dari keramaian. Padahal, didaerah yang masih sepi penduduk, seringkali dibangun perusahaan dan pabrik besar. Limbah dan polusi dari pabrik besar tersebut dapat mencemari lingkungan. Pencemaran lingkungan juga dapat merusak kesehatan penduduk sekitar pabrik. Pencemaran tersebut dapat meningkatkan produksi radikal bebas. Salah satu penyebab kerusakan sel atau jaringan adalah karena terjadinya stress oksidatif oleh radikal bebas. Sistem biologic dapat terpapar oleh radikal bebas baik yang terbentuk endogen oleh proses metabolisme tubuh maupun eksogen seperti pengaruh radiasi ionisasi. Radikal bebas bersifat sangat reaktif, dapat menimbulkan perubahan biokimiawi dan merusak berbagai komponen sel hidup seperti protein, lipid, karbohidrat dan nukleat. Membran sel terutama terdiri dari komponen-komponen lipid. Serangan radikal bebas terhadap komponen lipid akan menimbulkan reaksi peroksidasi lipid yang menghasilkan produk yang bersifat toksik terhadap sel. Dengan bertambahnya usia, kerusakan sel akibat stress oksidatif tadi menumpuk selama bertahun-tahun sehingga terjadi penyakit-penyakit degeneratif, keganasan, dan kematian selsel vital tertentu. Oleh sebab itu, banyaknya angka kejadian DM di tingkat pendidikan SD kemungkinan dikarenakan faktor pencemaran lingkungan di daerah pemukiman masyarakat dengan tingkat pendidikan rendah, bukan karena pengaruh tingkat pendidikan. Sehingga, tidak ada hubungan yang signifikan antara angka kejadian DM dan tingkat pendidikan.

Jenis pekerjaan juga erat kaitannya dengan kejadian DM. Variabel pekerjaan ini memiliki kaitan dengan aktifitas fisik. Aktivitas fisik dapat mengontrol gula darah. Glukosa akan diubah menjadi energi pada saat beraktivitas fisik. Aktivitas fisik mengakibatkan insulin semakin meningkat sehingga kadar gula dalam darah akan berkurang. Pada orang yang jarang berolahraga, zat makanan yang masuk ke dalam tubuh tidak dibakar tetapi ditimbun dalam tubuh sebagai lemak dan gula. Jika insulin tidak mencukupi untuk mengubah glukosa menjadi energi maka akan timbul DM (Trisnawati dan Soedijono, 2013).

Berdasarkan Tabel 1, menunjukkan bahwa karakteristik pasien DM berkaitan erat keluarga yang memiliki sejarah penderita DM. Responden yang memiliki keluarga dengan DM harus waspada. Risiko menderita DM bila salah satu orang tuanya menderita DM adalah sebesar $15 \%$. Jika kedua orang tua memiliki DM maka risiko untuk menderita DM adalah 75\%. Risiko untuk mendapatkan DM dari ibu lebih besar 10$30 \%$ dari pada ayah dengan DM. Hal ini dikarenakan penurunan gen sewaktu dalam kandungan lebih besar dari ibu. Jika saudara kandung menderita DM maka risiko untuk menderita DM adalah $10 \%$ dan $90 \%$ jika yang menderita adalah saudara kembar identik. Bagi masyarakat yang memiliki keluarga yang menderita DM, harus segera memeriksa kadar gula darahnya karena risiko menderita DM besar (Trisnawati dan Soedijono, 2013).

\section{Penggunaan Obat Pasien Diabetes Mellitus}

sebagai suatu penyakit kelainan metabolik kronis secara serius yang memiliki dampak signifikan terhadap kesehatan yang ditandai dengan tingginya kadar gula dalam darah. Salah satu penyebab diabetes mellitus yaitu 
menurunnya hormon insulin yang diproduksi oleh sel beta pulau Langerhans dalam kelenjar pankreas. Insulin merupakan hormon yang berperan dalam metabolisme glukosa khususnya sebagai perantara masuknya glukosa dalam darah ke sel-sel jaringan tubuh lainnya seperti otot dan jaringan lemak.
Dari keseluruhan data yang dikumpulkan didapatkan obat yang digunakan berdasarkan peresepan dokter yaitu Metformin, Novorapid, Levemir, Sanulin R, Sanulin N, Glibenklamid, dan Glimepirid. Obat biasa digunakan dalam dua kombinasi, 3 kombinasi, atau tanpa kombinasi.

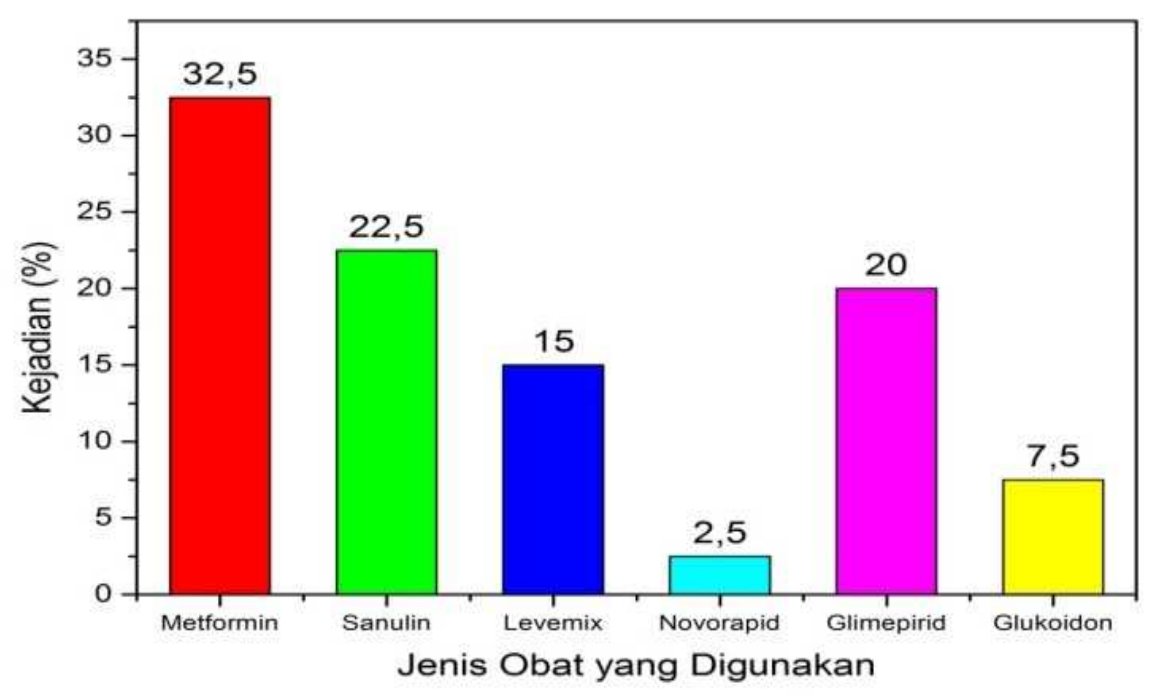

Gambar 1. Diagram Jenis Obat Pasien Diabetes Mellitus di Rumah Sakit Panglima Sebaya Paser Tahun 2013

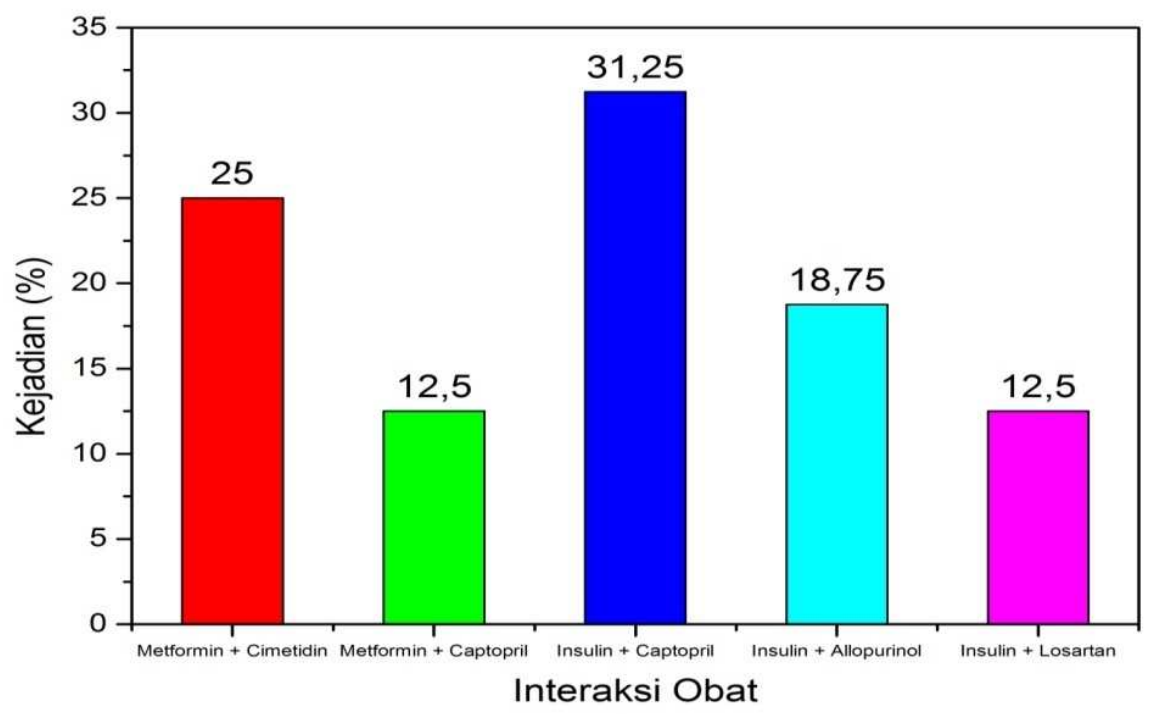

Gambar 2. Diagram Interaksi obat Diabetes mellitus Pasien Diabetes Mellitus di Rumah Sakit Panglima Sebaya Paser Tahun 2013 
Berdasarkan gambar 1 menunjukkan penggunaan obat pasien diabetes mellitus terbanyak adalah metformin yang merupakan golongan Biguanid sebesar 32,5\% diikuti sanulin $\mathrm{R}$ dan $\mathrm{N}$ sebesar 22,5\%, Levemir sebesar $15 \%$, Novorapid sebesar 2,5\%, Glimepirid sebesar 20\%, dan Glikuidon $7,5 \%$.

Mekanisme kerja golongan obat biguanid melalui perangsangan sekresi insulin tetapi langsung terhadap organ sasaran. Pemberian biguanid pada orang non-diabetik tidak menurunkan kadar glukosa darah, tetapi sediaan biguanid ternyata menunjukkan efek potensiasi dengan insulin. Metformin adalah obat antidiabetes yang paling sering diresepkan karena metformin bekerja langsung pada organ sasaran, sehingga efek obat signifikan. Selain itu, obat ini memiliki efek samping yang rendah dan harganya yang tidak terlalu mahal. Obat ini mampu menjaga kadar gula dalam darah tanpa menyebabkan hipoglikemia. Metformin juga aman dikonsumsi oleh ibu hamil. Metformin tidak dimetabolisme dan langsung diekskresikan di ginjal. Metformin juga dapat digunakan pada pasien obesitas.

\section{Interaksi Obat Antidiabetes dengan Obat Lain}

Berdasarkan data interaksi obat pada gambar 2. dapat dilihat bahwa terdapat 11 kasus interaksi dari 30 pasien. Ada kemungkinan dalam satu pasien terdapat lebih dari 1 kasus interaksi dan ada pasien yang tidak mengalami kasus interaksi. Interaksi yang paling banyak terjadi adalah interaksi obat Insulin dengan captopril sebesar 46\%, selanjutnya metformin dengan cimetidin sebesar 36\% dan insulin dengan losartan sebesar $18 \%$.

Berdasarkan Stockley's Drug Interaction Eight Edition tahun 2008, Metformin berinteraksi dengan obat captopril dan cimetidin. Penggunaan metformin dengan captopril biasanya pada pasien diabetes mellitus yang juga menderita hipertensi. Interaksi antara metformin dengan ACEI (Angiotensin Converter Enzyme Inhibitor) terutama captopril dapat meningkatkan resiko terjadinya hipoglikemia. Karena ACEI bekerja dengan mencegah perubahan angiotensin I menjadi angiotensin II sehingga terjadi vasodilator endothelial yang menyebabkan terjadinya penurunan tekanan darah. Terjadinya vasodilator menyebabkan terjadinya peningkatan distribusi insulin yang disertai dengan peningkatan produksi insulin. Hal tersebut menyebabkan terjadinya hipoglikemia. Selain itu, pada pemberian metformin dengan cimetidin menimbulkan interaksi farmakokinetik. Interaksi yang terjadi yaitu pada pemberian $800 \mathrm{mg}$ metformin sehari dapat menurunkan klirens ginjal 27\% dan meningkatkan kadar AUC (Area Under Curve) sebesar $50 \%$. Hal tersebut terjadi karena area kinetika interaksi antara metformin dengan antagonis reseptor $\mathrm{H}_{2}$ adalah ekskresi. Cimetidin memperlambat ekskresi metformin oleh ginjal. Terjadi interaksi ekskresi obat karena perubahan transpor aktif yakni pada pengangkutan obat dari darah melintasi sel-sel tubulus proksimal masuk ke urin. Penghambatan ekskresi metformin oleh cimetidin dapat menurunkan klirens metformin, sehingga meningkatkan kadar metformin, efek antihiperglikemik meningkat. Selain itu cimetidin juga mengikat sitokrom P-450 dan menurunkan kerja enzim mikrosom hati sehingga obat yang diberikan bersamaan dengan cimetidin akan terakumulasi di dalam darah (Aziz, 2002).

Interaksi Insulin dengan Captopril dan interaksi insulin dengan losartan dapat menimbulkan terjadinya hipoglikemia. Captopril merupakan obat penghambat yang kompetitif terhadap enzim pengubah angiotensin-I menjadi 
angiotensin-II / angiotensin converting enzyme (ACE). Captopril mencegah terjadinya perubahan dari angiotensin-I menjadi angiotensin II. Losartan merupakan obat yang secara selektif dan kompetitif bekerja terhadap subtipe reseptor AT1, sehingga efek Angiotensin II terhambat. Perubahan angiotensin Iangiotensin II dapat menyebabkan vasokontraksi dan kerusakan endotel. Pencegahan perubahan angiotensin Iangiotensin II juga berdampak pada peningkatan sensitivitas insulin. Angiotensin II (Ang II) mempengaruhi fosforilasi serine, pada reseptor insulin, insulin receptor substrate 1 (IRS-1) dan PI 3 Kinase yang berakibat pada gangguan "insulin signaling" Hambatan pada Renin Angiotensin System (RAS) merupakan kontra aksi terhadap gangguan signal insulin oleh Ang II. Mekanisme lain hambatan RAS memperbaiki sensitivitas terhadap insulin adalah: (1) vasodilatasi yang menyebabkan aliran darah menuju otot skelet bertambah, (2) meningkatkan perbandingan serabut otot tipe 1 yang sensitif terhadap insulin, (3) berkurangnya Tumor Necrosis Factor alpha (TNF- $\alpha$ ) pada otot skelet. Efek meningkatkan sensitivitas terhadap insulin ini disertai dengan peningkatan kadar adiponektin. Hambatan RAS menyebabkan diferensiasi dari preadiposit menjadi adiposit yang kecil dan sensitif terhadap insulin, yang menyebabkan bertambahnya produksi adiponektin. Adiponektin adalah sitokin yang spesifik pada jaringan adiposa. Adiponektin mempengaruhi sensitivitas insulin sebab zat ini mampu meningkatkan fosforilasi tirosin di reseptor insulin dan insulin receptor substrate di sel otot. Hal ini akan mengurangi konsentrasi asam lemak di dalam sirkulasi dan mengurangi kadar trigliserida di dalam otot dan hati. Adiponektin juga dapat mengurangi adhesi macrofag dan monosit pada endothelium, mencegah pembentukkan sel foam dan menghambat proliferasi sel otot halus di jaringan vaskuler. Dengan meningkatnya sensitifitas insulin maka produksi insulin endogen akan meningkat. Penambahan insulin eksogen akan menyebabkan akumulasi insulin yang meningkatkan resiko hipoglikemia. Oleh sebab itu, kombinasi captopril/losartan dengan insulin dapat menimbulkan hipoglikemia.

\section{KESIMPULAN}

Berdasarkan penelitian yang telah dilakukan dapat disimpulkan bahwa Tipe diabetes yang tedapat di Rumah Sakit Panglima Sebaya Paser Tahun 2013 adalah Diabetes Mellitus tipe 2 dengan jumlah pasien sebanyak 1.148 pasien. Berdasarkan kajian karakteristik pasien diabetes mellitus di Rumah Sakit Panglima Sebaya Paser tahun 2013, presentase pasien diabetes mellitus terbanyak berusia $45-59$ tahun $(51,65 \%)$, berjenis kelamin wanita $(66,64 \%)$, berpendidikan SD $(34,6 \%)$, tidak bekerja (86,9\%), dan memiliki sejarah keluarga pengidap diabetes mellitus $(55,6 \%)$. Obat yang paling banyak digunakan pada terapi diabetes mellitus di Rumah sakit panglima Sebaya Paser tahun 2013 adalah Metformin (32,5\%) dari golongan biguanid. Interaksi obat secara teoritis yang paling banyak terjadi pada penggunaan obat antidiabetes dengan obat lain yaitu Insulin dengan captopril $(46 \%)$.

\section{DAFTAR PUSTAKA}

1. Badan Penelitian dan Pengembangan Kesehatan, 2013.Riset Kesehatan Dasar 2013. Kementrian Kesehatan RI: Jakarta.

2. Clowes Williams, Beccles, Suffolk.2008. Stockley's Drug Interactions Eight Editions. Pharmaceutical Press : London.

3. Corwin, E. J., 2000. Buku Saku Patofisiologi (Handbook of Pathophysiology). Penerbit Buku Kedokteran EGC: Jakarta. 
4. Davey, P., 2006. Medicine at A Glance. Penerbit Erlangga: Jakarta.

5. Delamater, A. M., 2006. Imroving Patient Adherence.Clinical Diabetes. 24. (2). 71-77.

6. Dipiro, J., dkk., 2009. Pharmacotherapy Handbook Seventh Edition. McGraw-Hill Medical: New York.

7. Dwiprahasto, I., 2004.Medical Error di Rumah Sakit dan Upaya Untuk Meminimalkan Resiko.Jurnal Manajemen Pelayanan Kesehatan. 7. (1). 13-17.

8. Gilman, A.G., 2007. Dasar farmakologi Terapi Volume 2, Penerbit EGC: Jakarta.

9. Gitawati, Retno.2008.Interaksi Obat Dan Beberapa Implikasnya. Media Litbang Kesehatan. 18. (4). 175-177.

10. Himawan, J. Indra, Aman B. Pulungan, Bambang Tridjaja, Jose R.L. Batubara, 2009. Komplikasi jangka pendek dan jangka Panjang Diabetes Mellitus Tipe 1. Sari Pediatri. 10. (6). 367-368.

11. International Diabetes Federation. 2011. Diabetes Evidence Demands Real Action from the UN Summit on Non-Communicable Diseases. http://www.idf.org/diabetes-evidencedemands-real-action-un-summit-noncommunicable-diseases. Diakses pada tanggal 30 Juni 2014.
12. Irawan, Dedi. 2010. Prevalensi dan Faktor Risiko Kejadian Diabetes Melitus Tipe 2 di Daerah Urban Indonesia (Analisa Data Sekunder Riskesdas 2007). Thesis Universitas Indonesia.

13. Kementerian Kesehatan. 2010. Petunjuk Teknis Pengukuran Faktor Risiko Diabetes Melitus

14. Susilowati, Sri, dan Wiwit Pamuji Rahayu, 2008. Identifikasi Drug Related Problems(DRPs) Yang Potensial Mempengaruhi Efektivitas Terapi Pada Pasien Diabetes Mellitus Tipe II rawat Inap Di RSUD Tugurejo Semarang Periode 20072008, Skripsi, Fakultas Farmasi Universitas Wahid Hasyim, Semarang, hal 1-7.

15. Triplitt, C.L., Reasner, C.A., and Isley, W. L., 2005, Diabetes Melitus, in Dipiro, J. T., Talbert, R. L., Yee, G. C., Matzke, G. R., Wells, B. G., Posey, L.M., (eds), Pharmacotherapy A Pathophysiologic Approach, sixth Edition, Appleton and Lange, Stanford Conneticut, hal 1334-1352.

16. Trisnawati, Shara Kurnia dan Soedijono Setyorogo, 2013, Faktor Risiko Kejadian Diabetes Melitus Tipe II Di Puskesmas Kecamatan Cengkareng Jakarta Barat Tahun 2012, 5. (1). 6-10. 